\title{
Pasture-Based Dairy Systems in Temperate Lowlands: Challenges and Opportunities for the Future
}

\author{
Luc Delaby $^{1 *}$, John A. Finn ${ }^{2}$, Guylain Grange ${ }^{2,3}$ and Brendan Horan ${ }^{4}$ \\ 'INRAE, Agrocampus Ouest, Physiologie, Environnement, Génétique pour l'Animal et les Systèmes d'Elevage, Saint Gilles, \\ France, ${ }^{2}$ TEAGASC, Environment, Soils and Land-Use Research Department, Johnstown Castle, Wexford, Ireland, ${ }^{3}$ Trinity \\ College Dublin, School of Computer Science and Statistics, College Green, Dublin, Ireland, ${ }^{4}$ TEAGASC, Grassland Research \\ Science Department, Animal and Grassland Research and Innovation Centre, Moorepark, Fermoy, Ireland
}

OPEN ACCESS

Edited by: Pablo Gregorini, Lincoln University, New Zealand

Reviewed by: Maria Conceição Caldeira, University of Lisbon, Portugal

Sergio C. (Yani) Garcia,

The University of Sydney, Australia

*Correspondence: Luc Delaby luc.delaby@inrae.fr

Specialty section:

This article was submitted to Agroecology and Ecosystem Services,

a section of the journal Frontiers in Sustainable Food Systems

Received: 17 March 2020 Accepted: 30 November 2020 Published: 22 December 2020

Citation:

Delaby L, Finn JA, Grange G and Horan B (2020) Pasture-Based Dairy Systems in Temperate Lowlands: Challenges and Opportunities for the

Future.

Front. Sustain. Food Syst. 4:543587. doi: $10.3389 /$ fsufs. 2020.543587
Improved efficiency in dairy systems is a significant challenge for the future, to meet increased food demand while competing for inputs, adapting to climate change, and delivering ecosystem services. Future grazing systems can play a major role to supply healthier foods within systems with a reduced reliance on fossil fuels and chemical inputs, while also delivering environmental, biodiversity, and animal welfare benefits. Can we design lower-input systems that deliver efficient levels of output in a positive environmental context? Lower-input systems will have a lower reliance on concentrates and inorganic fertilizers, and an increased reliance on extended grazing seasons and high quality forage. Multiple strategies will be needed to maximize nitrogen use efficiency, including a strong reliance on legume-based swards that displace inorganic nitrogen fertilizer. Expected environmental benefits include a reduction in GHG emissions and nitrate leaching, an increase in $\mathrm{C}$ sequestration and a reduced reliance on the use of herbicides and pesticides. In comparison with confinement feeding systems, the relatively low energy density and high climate sensitivity of grazing diets requires both effective pasture management and robust and adaptive animals. The appropriate cow for grazing systems must be able to harvest pasture efficiently by re-calving every 365 days to efficiently utilize peak pasture supply, achieve large intakes of forage relative to their genetic potential for milk production (i.e., aggressive grazers) and be adaptable to fluctuations in feed supply. Legume-based multi-species grassland mixtures can maximize the use of symbiotically-fixed nitrogen, and displace the use of inorganic $\mathrm{N}$ fertilizer. There is a need for system-scale experiments that use legume-based mixtures within paddocks, and in grassland leys within crop rotations. Moreover, lower-input systems will need a combined focus on research and knowledge transfer for rapid testing and implementation. New opportunities and requirements will arise as policy, society, and the markets demand a higher level of environmental sustainability from food systems and products. This raises the possibility of public-private partnerships for the demand and reward of provision of environmental benefits. To deliver these benefits, future food systems will need to be redesigned to incorporate the enhanced supply of a range of ecosystem goods and services, which should be better incentivized through the market price returned to producers.

Keywords: dairy cows, pasture, sustainable grazing, biodiversity, policy, ecosystem services 


\section{INTRODUCTION-CHANGING DEMANDS ON FOOD SYSTEMS AND CLIMATE SMART FARMING}

Across the world, agriculture plays a crucial role not only in supplying food, but in shaping rural areas, preserving landscapes and cultural practices and heritage. The coming decades are likely to see increased pressures on agricultural systems, to continue to provide for an expanding and increasingly wealthy global population, and on the supply side, from greater competition for inputs and climate change (Godfray and Garnett, 2014; Zijdeman and Ribeira da Silva, 2014). The world's population is expected to grow from 7.6 to 10 billion between 2017 and 2067 (FAO, 2017) while the global demand for milk is expected to increase by $48 \%$ between 2005 and 2050 (Alexandratos and Bruinsma, 2012). As global incomes increase, diets typically shift from those comprised of mostly grains, to diets that contain a greater proportion of meat, dairy, and eggs (Tilman et al., 2011; Kastner et al., 2012). It is estimated $\sim 40 \%$ of the world's population will undergo this dietary shift by the year 2050 (Delgado et al., 2009). Society has grown accustomed to low food prices and at the same time, expects agriculture's environmental footprint to be reduced, to protect biodiversity and to provide products of unprecedented nutritional value. The longstanding challenge of achieving global food security through sustainable agriculture is particularly acute as world agriculture is a leading pressure on the environment. Today, global agriculture, forestry and other land use activities account for $13 \%$ of carbon dioxide (CO2), $44 \%$ of methane (CH4), and $81 \%$ of nitrous oxide (N2O) emissions from human activities globally, representing $23 \%$ of total net anthropogenic emissions of GHGs (IPCC, 2019). At the same time, loss of biodiversity and pressures on ecosystem services are among the most pressing global environmental challenges while land cover and land use change are leading contributors to habitat fragmentation, habitat loss and reduced biodiversity (Newbold et al., 2015; Ceballos et al., 2017).

In the past 50 years, growth in demand for food has been met primarily by steady increases in agricultural productivity driven by the intensification of agricultural production supported by increased use of monoculture crops and an increasing reliance on chemical fertilizers and herbicides (Arneth et al., 2019). Since 1961, the total production of food (cereal crops) has increased by $240 \%$ (until 2017) because of land area expansion and increasing yields (IPCC, 2019). Continued productivity gains from these practices are now increasingly uncertain while antagonistic environmental impacts such as more intense competition for natural resources, increased greenhouse gas emissions, and further deforestation and land degradation are anticipated (FAO, 2017). The global rate of annual yield increase of cereal crops has steadily declined from $3.2 \%$ in 1960 to $1.5 \%$ in 2000 (FAO, 2009) while the initial impacts of climate change and global warming are already resulting in reducing yields in the most sensitive regions (Kornhuber et al., 2019). Consequently, new agricultural technologies that can reinvigorate productivity gains and enhance agricultural/food system efficiency are now critical to meet global food security goals. In the European Union
(EU), the newly proposed EU Green Deal (EU, 2019) is an integral part of this EU Commission's strategy to implement the United Nation's 2030 Agenda and the sustainable development goals (UN, 2015). In addition to the productivity challenge, these proposals require $\mathrm{EU}$ food systems to become more transparent, continuing to supply healthy nutritious food from traceable production models, while simultaneously reducing environmental impact, supporting increased biodiversity and improved animal welfare, and reducing the use of hormones, agro-chemicals and antibiotics.

On that basis, the objective of this paper is firstly, to redefine the objectives and products of modern climate-smart dairy systems and secondly, in the particular case of temperate lowland grazing systems, to explore selected primary opportunities to realize these benefits within future systems. Although we do not exclude the application of these ideas to non-EU temperate regions, we acknowledge that our experience and perspectives are largely shaped by the EU context. We begin by outlining the contribution of intensively managed temperate grasslands to food production. We then discuss the demands of pasture-based systems on the dairy animal, and how these might be better addressed. We provide an overview of the potential contribution of multi-species grassland mixtures to nutrient efficiency and more sustainable grassland production. We conclude with a discussion of biodiversity and ecosystem services from dairy pastures, and the role of public and market-based payments to better incentivise the delivery of such services.

\section{REDEFINING THE PROCESSES AND DESIRED PRODUCTS FROM CLIMATE SMART FOOD SYSTEMS}

While the intensification and regional specialization of the Green Revolution in Agriculture during the last 60 years has greatly increased productivity, it has also resulted in adverse consequences for the natural environment. The continued intensification of such systems is now questioned in many developed economies worldwide. Firstly, the high reliance of intensive dairy systems on mineral fertilizer inputs has resulted in reduced nutrient use efficiency and an increased risk of nutrient losses to air and water. In addition, the increased use of concentrates, and in particular imported soya bean and palm kernel, creates increased demand for such crops in developing economies thereby stimulating deforestation and environmentally harmful agricultural practices elsewhere around the world. Allied to these damaging impacts of intensification, the loss of landscape biodiversity arising from such farming practices, combined with the disappearance of habitats for small land animals, insects or birds is also important in the context of the contribution of livestock farming to GHG emissions and global warming. In light of these criticisms, and in response to consumer demand for more environmentally sustainable food products, dairy systems must be adapted and redesigned to continue to provide sufficient high quality nutritious foods in addition to an 


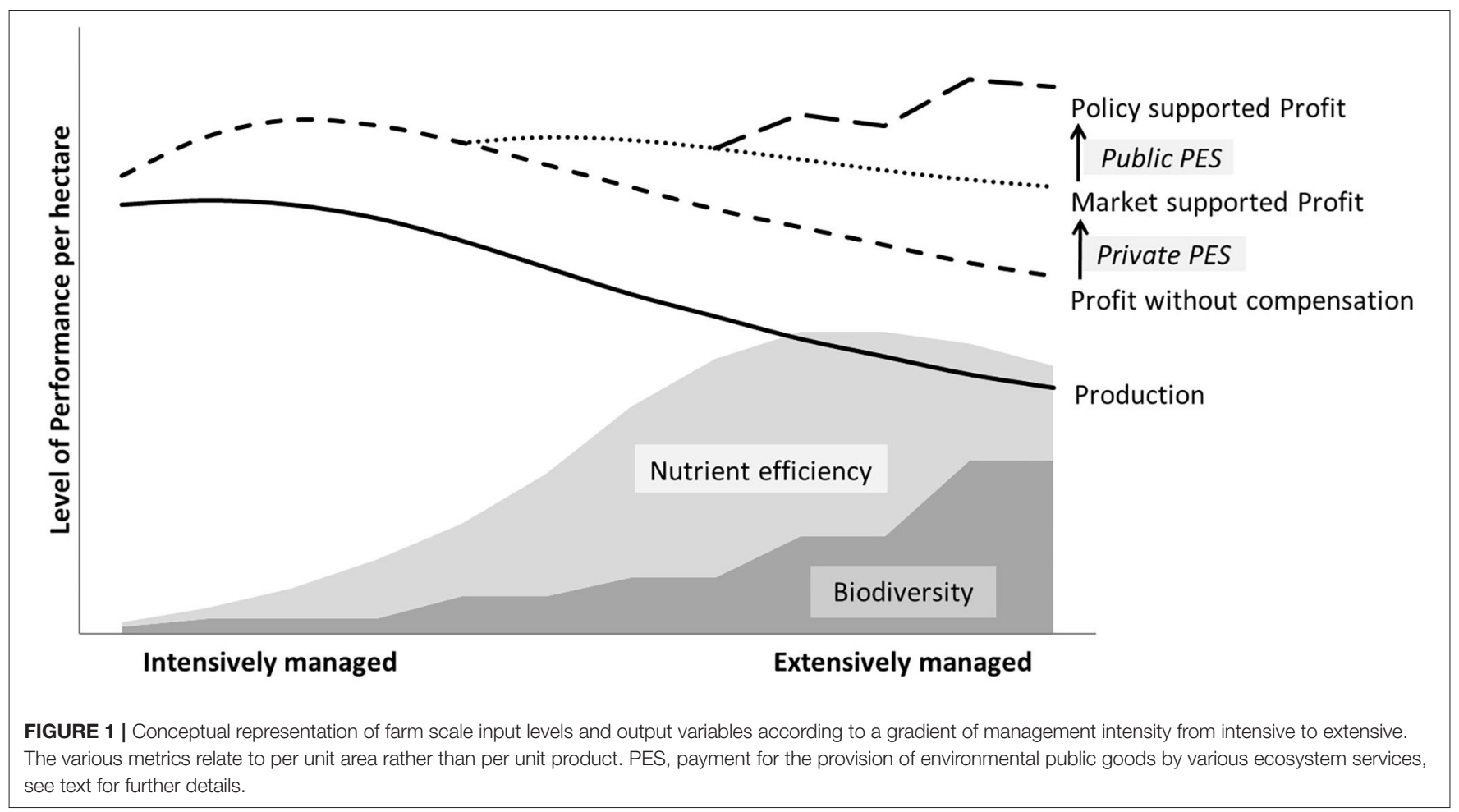

enhanced supply of ecosystem goods and services. This approach is conceptualized in Figure 1.

Although intensive dairy systems can achieve low levels of environmental impact when expressed per unit of product produced (Capper and Cady, 2020), the total level of environmental impact remains high when expressed per hectare of land farmed in more intensive systems while others aspects, which are poorly evaluated with the LCA approach, must also be considered (van der Werf et al., 2020). Therefore, as management intensity reduces, productivity per hectare or per animal will decrease and the reduction in per hectare productivity will occur commensurate with a reduction in environmental impact. Grassland nutrient use efficiency increases when inputs decrease, until an inflection when the low exportation rate results in a lower efficiency (Huguenin-Elie et al., 2018). Biodiversity mitigation in intensive systems is also difficult to achieve, with negligible increases in biodiversity until there is a major shift to more extensive practices (in a land sharing approach). For example, going from $250 \mathrm{~kg} \mathrm{ha}^{-1}$ to $200 \mathrm{~kg} \mathrm{ha}^{-1}$ of inorganic $\mathrm{N}$ fertilizer has negligible effects on grassland biodiversity, compared to going from 50 to $0 \mathrm{~kg} \mathrm{ha}^{-1}$ (Kleijn et al., 2009). In essence, biodiversity conservation within dairy systems will only be achieved by protecting and improving the quality of adjoining wildlife habitats. For this reason, part of on-farm biodiversity enhancement can be achieved with relatively minor impact on production as the land areas most likely to be beneficial for biodiversity are likely to be those which are least suitable for dairy production e.g., areas of wetlands, woodlands, hedgerows, wet grasslands etc. Farm profitability (per hectare) will also reduce initially as productivity is reduced, however the reduction in profitability will at a lower rate than that for production. This is because the marginal profitability of extra production is lower for each additional unit of productivity within intensified systems due to increased marginal costs associated with intensification (Ramsbottom et al., 2015).

Finally, in our opinion, there is a non-linear relationship between production and profit and environmental impact according to the level of management intensity. A key challenge is to re-design farming systems so that required standards of environmental quality are delivered with least impact on production and farm profits. For the system to be robust, losses in income to the farmer arising from de-intensification should be compensated for providing a just transition to a new farming system. On that basis, the provision of environmental public goods should also result in enhanced market prices for producers of such products, either promoted by consumers' preferences ("Market supported" in Figure 1), or supported by public payments for the provision of public goods ("Policy supported" in Figure 1), or a combination of both. Such advanced market systems already occur in some countries such as Switzerland, France and Germany (see below).

\section{THE EVOLVING ROLE OF LOWLAND TEMPERATE GRASSLAND IN FOOD SYSTEMS}

Grasslands cover more than $40 \%$ of the earth land surface (excluding Greenland and Antartica) with a large diversity of vegetation (White et al., 2000). While grazing land is the single 
largest land-use category, the intensity of land use varies hugely within and among different land-use types, and regions with $\sim 10 \%$ of the total ice-free land surface managed intensively (Erb et al., 2016). A large part of the total grassland area is composed of native or natural grassland such as the savanna in Africa, the pampa in South America, shrub land and steppes in Oceania and Asia and tundra in Europe. Indeed, intensive and semi-intensive grasslands represent only a minor component (2\%) of total land use (Figure 2; IPCC, 2019). Within the spectrum and context of future food systems, the specific case of temperate lowland grazing-based production is deserving of specific attention. In an EU context, improving the efficiency of grazing production systems is considered as the greatest opportunity to develop climate smart farming systems for the future.

In addition to forage production, grasslands play a major role in ecosystem equilibrium including biodiversity preservation, carbon storage, erosion control, water and nutrient cycling regulation (O'Mara, 2012; Soussana and Lemaire, 2014; Plantureux et al., 2016). In addition to the provision of these benefits, the role of grasslands in efficiently converting human inedible feed to high quality human nutrients has been acknowledged (Mottet et al., 2017; Peyraud, 2017). These systems are commonly practiced in temperate lowlands (such as Europe, New Zealand, and South America), are highly competitive and make a significant contribution to global food supplies. Similar to other food systems however, the intensification of grazing systems in the last 50 years using cheap mineral fertilizers and feed supplements has helped to increase management control and productivity in grazing systems. Consequently, today's pasture-based dairy systems can be described as semi-intensive or intensive systems with high levels of mineral nitrogen fertilizers, concentrates and irrigation applied to increase feed supply and reduce variability. In terms of feeding systems, they are increasingly specialized based on monocultures of sown grass or integrated in crop-livestock systems where grass and maize silage coexist (Table 1). Moreover, while grazing systems are widely recognized for the positive impacts on animal health and welfare (EU, 2009), the reduction in grazing season length, associated with the intensification of the EU dairy industry is now among the main animal welfare concerns for the sector (Nalon and Stevenson, 2019).

\section{DESIGNING CLIMATE-SMART TEMPERATE GRAZING SYSTEMS}

In the context of the desired evolution in climate-smart food systems (outlined in the previous section) we identify and discuss three pertinent issues for temperate lowland grazing systems. There are many others possibilities such as, for example, to better utilize the complementarity within integrated cropslivestock farming (Ryschawy et al., 2017), but we believe that the required increase in resilience and environmental benefits in temperate lowland grazing based dairy systems will be primarily based on the adaptation of livestock, feeding systems and ecosystem services. We discuss three specific changes

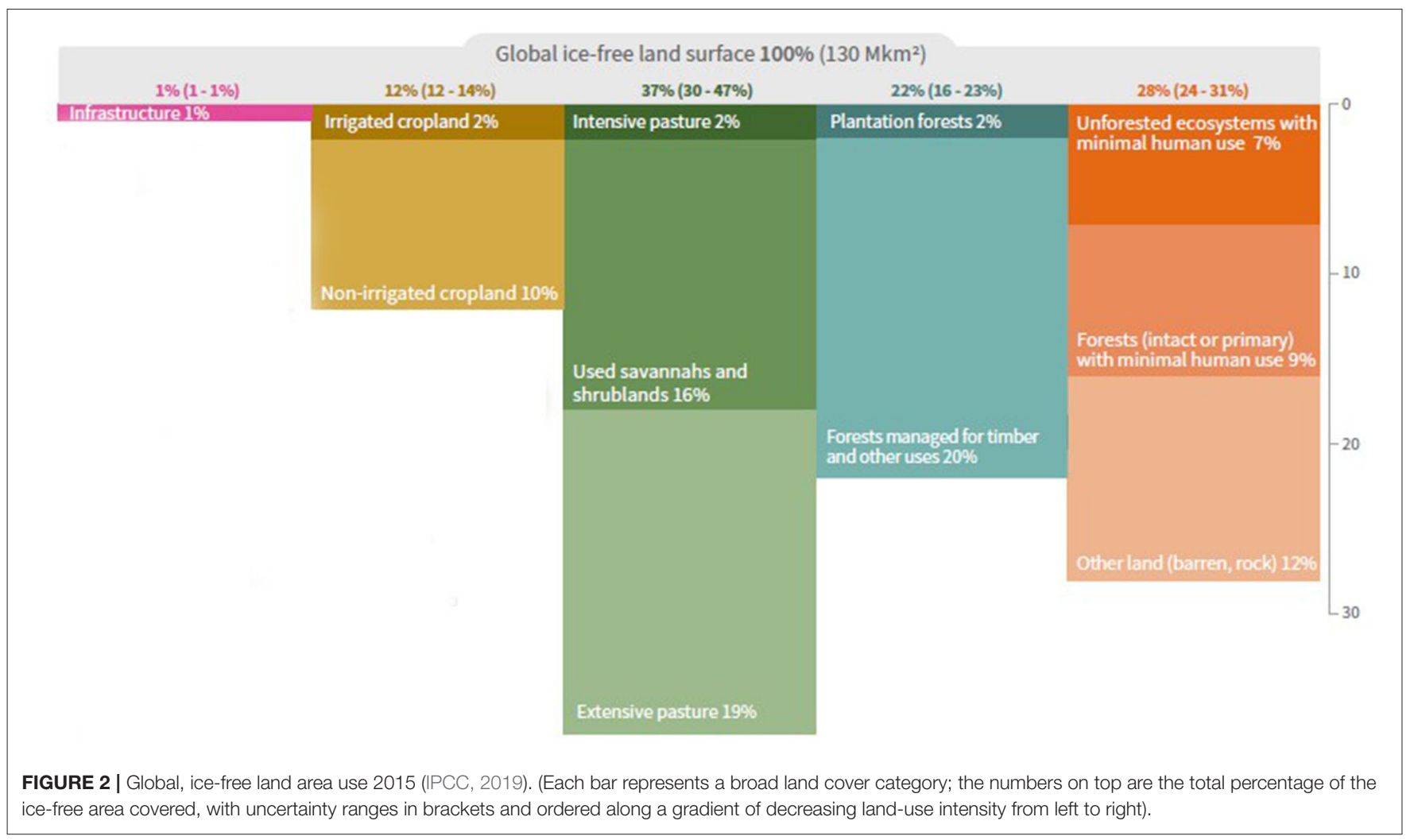


TABLE 1 | Main characteristics of some pasture-based dairy systems in temperate lowlands (These data represent average values, and are derived from diverse national statistical publications).

\begin{tabular}{lcccc}
\hline & France & Ireland & Netherlands & New Zealand \\
\hline Herd size (cows) & 75 & 80 & 90 & 435 \\
First lactation (\%) & 32 & 23 & 27 & 22 \\
Milk yield (kg/cow) & 7000 & 5000 & 8700 & 4200 \\
Calving interval (days) & 420 & 395 & 420 & 370 \\
Concentrate (kg/cow) & 1300 & 1000 & 2000 & 600 \\
N mineral (kg/ha) & 70 & 180 & 130 & 150 \\
Grassland area (\%) & 50 & 95 & 70 & 90 \\
Forage crop area (\%) & 50 & 5 & 30 & 10 \\
Stocking rate (cow/ha) & 1.70 & 2.00 & 2.50 & 2.85 \\
\hline
\end{tabular}

${ }^{a}$ Calculated on the area used to feed the dairy cows.

to farm practices namely; the selection of cows adapted to grazing, the development of multi-species pastures and the promotion of biodiversity and associated ecosystem services through semi-natural habitats.

\section{MATCHING THE COW TO THE SYSTEM}

In livestock farming systems, the animal is a key component of an efficiently working system. In low-input, pasture-based systems, more than others, the dairy cow is a feed-to-food transformer, converting grass to milk. In these systems, increasing the proportion of grazed grass in the annual feeding budget reduces total costs and increases farm returns (Ramsbottom et al., 2015). Consequently, the dairy cow must possess critical attributes, which are associated with the particularities of the grass-based systems of production.

In grazed grass-based systems, three main aspects should be highlighted to define the "ideal" animal. By construction, the feeding resource is based on forages defined with a higher fill value and a lower energy nutritive value than concentrate based feeding. Secondly, to manage grazing with high efficiency and a low post grazing residual height, the grass offered restricts the expression of the animal intake capacity. Finally, this resource is naturally seasonal, unstable, and uncertain with huge variation in feed supply due to the sensitivity to climate variation.

The first consequence, resulting from the two first specifications of the grazed based system is the failure to fully meet the nutritional requirements of high genetic merit dairy cattle for milk yield within a grass only diet. This is illustrated by Bargo et al. (2002) with their experiment comparing indoor and grazing feeding systems. The total daily dry matter intake, milk yield and milk solids were lower $(-5.1,-9.6$, and $-0.69 \mathrm{~kg}$, respectively) for grazing dairy cows. With such high demands for energy and protein, due to the continental Holstein milk yield potential, grass intake is unable to satisfy completely the mammary gland requirements. In this situation, although the grass nutritive value (energy, protein content) is high, the overall level of intake achieved is inadequate. With genetic selection based mainly on milk yield, the dairy cow intake capacity
TABLE 2 | Dairy cows performance observed in the INRAE Le Pin experiment (The cow for the system?-2006-2019) and in the Teagasc NGH experiment (Next Generation Herd-2013-2016) in comparison with the objective for grass-based dairy system and compact calving management (12 weeks calving period).

\begin{tabular}{|c|c|c|c|c|c|c|c|}
\hline \multirow{3}{*}{$\begin{array}{l}\text { Breed } \\
\text { Feeding level }\end{array}$} & \multirow[t]{3}{*}{ Objective } & \multicolumn{4}{|c|}{ The cow for the system? ${ }^{a}$} & \multicolumn{2}{|c|}{$\mathrm{NGH}^{\mathrm{b}}$} \\
\hline & & \multicolumn{2}{|c|}{ Holstein } & \multicolumn{2}{|c|}{ Normande } & \multirow[t]{2}{*}{ NatAv } & \multirow[t]{2}{*}{ Elite } \\
\hline & & High & Low & High & Low & & \\
\hline Milk yield (kg) & & 8360 & 6000 & 6200 & 4625 & 5810 & 5610 \\
\hline Milk solids (kg) & & 568 & 411 & 457 & 342 & 451 & 459 \\
\hline $\begin{array}{l}\text { BCS at calving [pts } \\
(0-5)]\end{array}$ & & 2.80 & 2.65 & 3.40 & 3.05 & 3.00 & 3.25 \\
\hline BCS losses [pts(0-5)] & -0.50 & -0.90 & -1.15 & -0.60 & -0.80 & -0.40 & -0.40 \\
\hline $\begin{array}{l}\text { Interval calving }-1^{\text {st }} \\
\text { ovulation (days) }\end{array}$ & $25-30$ & 41 & 39 & 33 & 30 & / & / \\
\hline $\begin{array}{l}\text { Normal cyclicity profile } \\
\text { rate (\%) }\end{array}$ & 80 & 51 & 43 & 67 & 76 & / & / \\
\hline First Al in-calf rate (\%) & 60 & 36 & 29 & 43 & 41 & 46 & 60 \\
\hline 6 week in-calf rate (\%) & 70 & 40 & 36 & 49 & 52 & 58 & 73 \\
\hline 13 week in-calf rate (\%) & 90 & 60 & 56 & 73 & 70 & 83 & 93 \\
\hline
\end{tabular}

aHigh: In winter (100 days), early in lactation, total mixed ration with maize silage, dehydrated alfalfa, and concentrate, ad libitum. At grazing (180 days), 0.35 ha per cow, $4 \mathrm{~kg}$ concentrate, and $5 \mathrm{~kg}$ maize silage from July. In autumn (85 days), $5 \mathrm{~kg}$ maize silage, $4 \mathrm{~kg}$ concentrate, and grass silage ad libitum.

Low: In winter (100 days), early in lactation, total mixed ration with grass silage, and big bale haylage, ad libitum. At grazing (180 days), 0.55 ha per cow. In autumn (85 days), grass silage ad libitum. No concentrate. (updated from Delaby et al., 2018).

${ }^{b}$ Two genotypes based on Ireland's dairy selection index, the Economic Breeding Index (EBI): NatAv ( $n=45$ annually) representing national average based on EBI and Elite ( $n=90$ annually) representing the top 1\% (O'Sullivan et al., 2019, 2020).

increases but much less than the associated energy demand. Consequently, at grazing without supplementation, high genetic merit cows are unable to express their potential due to the form and nature of the forage offered. In the same way, in farmlet experiments comparing different types of cows managed at different feeding levels, the authors often report a phenotypic interaction on total milk and milk solids yield (Horan et al., 2005; Fulkerson et al., 2008). Comparing animal performance, typically, the greater the milk yield or milk solids potential of the cow, the greater the difference observed between high and low feeding treatments at grazing. Indeed, the milk production response to feeding level of high genetic merit cows is generally higher than for dual-purpose, crossbred, and lower genetic merit cows (Table 2; Delaby et al., 2014). Continuing to select on milk yield potential will lead to a nutritional impasse.

The final characteristics of grazed based production systems, associated with the seasonality of grass growth, has two main consequences in terms of herd management and animal robustness. The dairy farmers are highly motivated to synchronize herd demand with grass availability using compact calving in spring to maximize grass utilization (Delaby and Horan, 2017). In environments where a period of drought is probable during summer for example, and without irrigation or with severe restriction on water utilization, Pottier et al. (2007) have suggested keeping compact calving management but with two compact calving periods at 6-month intervals is appropriate. 
In this situation, half of the herd demand is associated with dry cows, in summer or in winter, the traditional period with reduced pasture growth. Two periods of compact calving can allow total feed requirements to be reduced on the grazing platform thereby allowing available pasture and the best-conserved forages to be dedicated to the milking cows during periods of feed restriction.

To obtain compact calving at the same time every year requires compact rebreeding before day 90 of lactation. For dairy cows, this period is early in lactation and concomitant with the peak of lactation. Due to the gap between intake and energy demand, increased peak milk production results in increased body reserve mobilization resulting in a reduced likelihood of successful timely rebreeding (Butler, 2014; Bedere et al., 2016, 2017). Typically, continental Holstein dairy cows are unable to conceive within the required short timeframe due to high milk production levels which are detrimental to the maintenance of adequate body condition to facilitate conception at the right moment and avoid ill health within a restricted feed environment (Table 2; Baumont et al., 2014; Delaby and Fiorelli, 2014). Consequently, a more appropriately balanced (milk plus fertility potential) dual purpose or cross breed cow with lower milk production and superior fertility is beneficial to maintain high fertility capacity which is essential for grazed grass based dairy systems (Washburn and Mullen, 2014). This has been done with success in Ireland. Starting 20 years ago, the definition and the application of an Economic Breeding Index has paid dividend (Berry et al., 2019). In comparison with national average genetic merit cattle, the performance of high EBI dairy cows in terms of milk yield, milk composition, and fertility are consistent with the ambition of this program (Table 2; O'Sullivan et al., 2019, 2020).

In the future, two or three main aspects must be kept in mind to further improve the animal capability to assume better grass based systems constraints. Firstly, in relation to animal health and welfare, selecting for a healthier cow will be the first step to improve animal welfare. Specifically at grazing, the selection of animals, which are resistant to lameness and parasitism to limit use of antibiotics and anthelmintic products, is an opportunity for the future. Some breeds such as Normande or Montbéliarde dairy cows are more sensitive than Holstein or Jersey or Kiwicross breeds to lameness, probably because of high animal bodyweight and hoof hardness which is underdeveloped for long walking distances. Resistance to parasitism is important for heifers during the first grazing season and it is well-known that parasitism sensitivity differs between animals and is heritable. In fact, some specific approaches based on selective anthelminthic treatment using standard growth curves and regular animal weighing must be further developed to reduce use and limit the anthelmintic footprint of food production in addition to the risk of anthelmintic resistance (Delaby, 2015). Such approaches to limit anthelminthic treatment must be further developed for the future.

A second concern for the future is the potential for more erratic grass growth patterns, as anticipated climate change will increase the frequency of negative hazards. The reduction in inorganic nitrogen fertilization and the control of water use for irrigation will also make the system more dependent on the natural processes of mineralisation and fixation. That may also contribute to increase pasture supply variability in future. Such system changes coupled with the increasing frequencies of unpredictable weather events will exacerbate the volatility of pasture supply and nutritive value (Lee et al., 2013), and will require future dairy cattle that can withstand periods of nutritional restriction. The ideal dairy cow should have the inherent capability to reduce milk yield during periods of restriction, to protect vital processes and thereafter, to rebound when forage supply recovers. To select on this capability, named plasticity (Friggens and Newbold, 2007), a methodology has to be developed to challenge the animal and observe their reactivity. In the short term, we know that the dairy cow is able to reduce milk yield during short term feed restrictions and preserve the mammary gland secretion potential. This is illustrated well with the milk yield profile observed in long residence time rotational grazing paddocks when grass availability declines between the first and the last day in the paddock (Roca-Fernandez et al., 2012). In the longer-term, this capability to recover mammary gland milk synthesis potential is modest and the carry over effect will depend mainly of the duration and severity of the restrictive feeding period, the dairy cow milk production potential and body reserves (Delaby et al., 2009).

Finally, as an integrative property, a well-adapted dairy cow for future grass based systems is a cow with greater longevity. Farmers describe "a transparent cow, a cow you never hear about" (Delaby et al., 2018). This cow is able to be in calf at the right moment, with no or few health problems, and produce high fat and protein content milk according to the feeding level available from grazed grass. In this situation, the replacement rate is low which helps to reduce environmental impacts such as the global GHG emissions of the dairy system (Dall-Orsoletta et al., 2019). In the same direction, reduced inorganic nitrogen use facilitated by the (re)introduction of legumes into pastures will also reduce GHG emissions and increase $\mathrm{N}$ efficiency. Improving the global efficiency of the system, with higher dairy cow durability will generally have a simultaneous positive effect on the environment.

\section{MULTI-SPECIES MIXTURES: BENEFITS OF DIVERSITY}

There has been renewed focus on the incorporation of legumes into intensive grassland-livestock systems. A wellmanaged legume proportion in a sown grassland (ideally 30$50 \%$ legume content) can result in higher productivity and reduced production costs (Suter et al., 2015). These savings are achieved through lower reliance on inorganic nitrogen $(\mathrm{N})$ fertilizer, a prominent variable cost in intensive dairy systems. In Switzerland, grass-legume mixtures receiving $150 \mathrm{~kg} \mathrm{ha}^{-1} \mathrm{yr}^{-1}$ of $\mathrm{N}$ fertilizer out-yielded grass monoculture receiving $450 \mathrm{~kg}$ $\mathrm{ha}^{-1} \mathrm{yr}^{-1}$ of $\mathrm{N}$ fertilizer when legume proportion comprised $30 \%$ or more of the vegetation biomass (Nyfeler et al., 2009). In a continental-scale experiment, four-species mixtures (two grasses and two legumes) consistently yielded better than the average of the four monocultures, and even yielded more than the best-performing monoculture in a majority of cases (Finn et al., 2013). Grange et al. (2019) also showed that combining 
competitive grass, legumes and forbs (with $150 \mathrm{~kg} \mathrm{ha}^{-1} \mathrm{yr}^{-1}$ of N fertilizer) achieved a fertilizer replacement value sufficient to outyield a perennial ryegrass monoculture with $300 \mathrm{~kg} \mathrm{ha}^{-1} \mathrm{yr}^{-1}$ of nitrogen.

Better nitrogen fertilizer use efficiency is associated with higher forage nitrogen content, thus, incorporating legumes can bring higher milk solids from a lower-input system (Harris et al., 1997; Egan et al., 2015). In addition, the inclusion of forbs in a grass-legume sward can bring extra yield and more complete feeding value, especially of minerals and bioactive secondary metabolites (Delagarde et al., 2014; Cranston et al., 2015; Cong et al., 2016). Despite the technical difficulty in quantifying the benefit of these metabolites in livestock health, we know that several husbandry pathologies can be tackled by a diverse diet that includes high concentrations in some of these metabolites (Poutaraud et al., 2017). In an example that differentiated grass and/or clover effects from grass+clover+herb vegetation, a 2-year study investigated lamb and ewe performance on perennial ryegrass only, perennial ryegrass and white clover, and a six-species and nine-species mixture. Lambs on the sixspecies mixture had heavier bodyweights and required fewer anthelmintic treatments than lambs grazing either perennial ryegrass or perennial ryegrass and white clover. Lambs grazing the perennial ryegrass sward required more days to reach slaughter weight than lambs grazing all other sward types (Grace et al., 2019).

On a broader scale, by diversifying plant species, we reduce the risk of deficiency in any aspect of an animal diet. To illustrate this in a 2-year grazing experiment (with $75 \mathrm{~kg} \mathrm{~N} \mathrm{ha}^{-1}$ $\mathrm{yr}^{-1}$ ) in France, an increase of botanical complexity from one to five species (two grasses, two clovers, and chicory) resulted in positive effects on animal performance (Roca-Fernández et al., 2016). They distinguished between monocultures of perennial ryegrass, grass-clover mixture, and "multi-species swards" of grasses, clovers, and chicory. Compared to grassclover, multi-species swards improved production of milk $(+0.8$ $\mathrm{kg} /$ day $)$ and milk solids $(+0.04 \mathrm{~kg} /$ day $)$, which was attributed to enhanced sward quality and increased dry matter intake $(+1.5 \mathrm{~kg} \mathrm{DM} /$ day). Compared to monocultures, plant richness also enhances grassland stability over seasons and weather disturbances. As climate change is leading to more extreme weather events such as summer drought (Hopkins and Del Prado, 2007), multi-species swards have shown better resistance than monocultures in several studies (Vogel et al., 2012; Isbell et al., 2015; Craven et al., 2016; Finn et al., 2018). When including forbs, multi-species swards contributed to increase carbon sequestration (Cong et al., 2014). Mixtures are also very stable against weed invasion which is another threat in intensive dairy systems (Connolly et al., 2018), and facilitates a reduced reliance on herbicides. In summary, increasing plant diversity in sown grasslands (to levels with four to eight selected species) is an example where better environmental performance can be achieved without any reduction in productivity, even when there is a reduction in farm inputs (Weigelt et al., 2009). In an economic analysis, (Schaub et al., 2020) found higher farm profitability and reduced production risk from multi-species grassland compared to a monoculture.

\section{BIODIVERSITY AND ECOSYSTEM SERVICE PROVISION}

Globally, there is an ongoing decline in both biodiversity and the provision of ecosystem services. Much of European biodiversity is associated with extensively managed farmland; agricultural intensification is a major driver of this decline through conversion (e.g., species-rich grassland or woodland is converted to cropland or forestry), fragmentation, homogenisation, and modification (overgrazing, undergrazing, and the application of nutrients and biocides) of habitats. Intensively managed farming systems, therefore, prioritize the delivery of selected provisioning services (food), at the expense of land uses that are favorable for biodiversity, and associated ecosystem services. Thus, it is perhaps not surprising that surveys of intensively managed farms show that most of the original farmland habitats have been removed, and there tends to be only small habitat fragments remaining. For example, farmland habitats in a survey of mostly grassland farms in Ireland reported semi-natural habitat areas of 14 and 13\% (Sheridan et al., 2011, 2017); Sullivan et al. (2011) reported an average of $15 \%$. In an Irish study of more intensively managed farms $(n=119)$, the wildlife habitat area across three separate farming enterprises (tillage, beef, and dairy) comprised almost $10 \%$ of the farm area. Linear features such as hedgerows, buffer strips and drainage ditches accounted for $43 \%$ of the total area of wildlife habitat surveyed, and hedgerows were the single most abundant wildlife habitat (Larkin et al., 2019). Looking at a gradient of farming intensity from extensive to intermediate to intensive, the Farm Ecos project in Ireland showed that the area of semi-natural habitat was $42 \%$ to $15.6 \%$ to $6.1 \%$, respectively (Rotchés-Ribalta et al., 2020). Overall, these studies demonstrate how intensive agricultural management such as occurs on most dairy systems is generally associated with a reduced area of habitat available for wild populations of plants and animals, and especially when there is low protection afforded to habitats by policy (Rotchés-Ribalta et al., 2020). There is also a wider off-farm impact of livestock systems that may not be captured by farmscale metrics e.g., biodiversity impacts that arise from conversion of tropical rainforest for cultivation of soy to supplement animal intake of protein, and biodiversity impacts from downstream impacts on water quantity. Importantly, the off-farm biodiversity impacts due to land use change can be as large as those that occur on-farm (Teillard et al., 2016); the greater the reliance on off-farm feed, the greater the impact. Methods to better assess the impact of livestock systems are under development (FAO, 2020).

There is a growing expectation from society for agricultural systems to improve their environmental sustainability, and to respond to the climate and biodiversity crises. Food production systems vary widely in their environmental sustainability, and the public perception of food production has become increasingly polarized.

What role can lower-input pasture-based dairy systems play to improve biodiversity? Some general guidance for habitat triage follows:

- Protect and maintain the appropriate management of existing natural habitats that support wild populations of plants and 
animals e.g., ponds, hedgerows, native woodland, peatlands, wetlands, heathlands etc.

- Enhance the wildlife quality of degraded farmland habitats through improved management.

- Only consider the creation of new wildlife habitats after existing habitats have been retained or enhanced.

- Do not locate newly created wildlife habitats on existing habitats.

In practice, within dairy systems, likely actions will include: protection and conservation of existing habitats with native vegetation and species; planting of new hedgerows; improved management of hedgerows to support more wildlife; widening of existing field margins; creation of field margins; creation of ponds and planting of small woodland areas. Excessive cutting and management of hedgerows removes flowers and food that supports a variety of invertebrate species (including pollinator species) and can destroy over-wintering insects. More appropriate management of hedgerows for wildlife involves trimming on rotation every second or third year. An example of a project undertaking demonstration of such actions is taking place in the Bride Valley, Cork, Ireland (BRIDE project www.thebrideproject.ie).

The benefits of such actions extend beyond the improvement in allocation of space for biodiversity. For example, for hedgerows and wooded areas (that are characteristic of many temperate landscapes in Ireland, and bocage in France), wider benefits include:

- Shelter and shade. Hedgerows and trees provide shelter from winds and cold weather. In addition, they also provide shade and protection from heat stress during warmer weather and heatwaves. The physical barrier provided by thick hedges contributes to reduced disease transmission among herds.

- Carbon sequestration. Hedgerows can also contribute to carbon sequestration: the greater the volume and age of the hedgerow, the more carbon is likely to be sequestered.

- Improved water infiltration. Water infiltration is higher adjacent to hedges, and can prevent lameness due to footsplaying and is less suitable to snails that are hosts to liver fluke.

- Improved pollination services. The diversity of plants and floral resources in diverse hedgerows provides habitat and food for wild pollinating insects. These will benefit adjacent crops that are pollination-dependent, as well as contributing to biodiversity.

- Biological control. Habitat diversity underpins the diversity of species that naturally contribute to the control of agricultural pests and diseases, and reduces the reliance on chemical methods of control.

- Landscape connectivity.

\section{MARKET AND POLICY ACTIONS TO ENHANCE BIODIVERSITY AND ECOSYSTEM SERVICES}

A number of possible market and policy actions are available to curb the greatest impacts of production systems, but also to actively enhance their positive contributions. In considering what unique role exists for lower-input dairy systems to improve biodiversity, some examples include:

- Voluntary actions by farmers. These are highly dependent on personal motivation, and availability of good advice for environmental management and biodiversity conservation. We do not discuss this any further here.

- Entry-level criteria that are associated with market access.

- Public payments for environmental public goods. Here, we give an example based on EU agri-environment schemes, and discuss recent developments that focus on results-based approaches and payments.

- Private initiatives/market-based incentives to reward provision of ecosystem services. We provide two case studies here.

Agri-food companies are undertaking sustainability assessments for compliance or benchmarking with international accreditation schemes. Increasingly, food processors are requesting that suppliers (farmers) attain minimum criteria as a condition of supply to the processor. In general, such approaches tend not to be very demanding, and are highly dependent on adequate compliance inspection and availability of adequate advice. In addition, such approaches tend to be more suited to preventing future impacts rather than restoring ecosystems that were impacted in the past. As one example of an international accreditation scheme, the Sustainability Assessment Initiative (SAI) Platform is a global initiative, and includes several biodiversity criteria (essential, basic, and advanced) in its Farm Sustainability Assessment (FSA) tool (www.saiplatform.org).

In the EU, the Common Agricultural Policy is an extremely prominent policy, and key instruments include: income support through direct payments that ensure income stability, and remunerate farmers for environmentally friendly farming and delivering public goods; market measures to deal with difficult market situations, and; rural development measures with national and regional programmes to address the specific needs and challenges facing rural areas. Within the Rural Development Programme, agri-environment schemes are intended to be a major contributor toward CAP objectives to reverse biodiversity decline and restore ecosystem services, improve good water quality and mitigate climate change impacts of food production. In the European Union, the primary source of funding for biodiversity conservation and ecosystem services now derives from agri-environment policies (reflecting the large relative size of the $\mathrm{CAP}$ to national and other funds for biodiversity conservation). In practice, the administrative workload and payment levels from agri-environment schemes are not sufficiently attractive for most dairy farmers, and they tend to have low participation levels in biodiversity actions as part of agri-environment schemes.

It is clear, however, that the business-as-usual, "one-sizefits-all" EU approach that has been characteristic of most agrienvironment schemes has failed to deliver the best biodiversity and ecosystem services outcomes, despite their considerable financial costs. There is a general acceptance among researchers and policymakers that agri-environment schemes need to be 
more focussed and better targeted to deliver verifiable results (ECA, 2011). In line with this expectation, a novel approach for the development of such schemes is to incorporate "resultsbased approaches" and payments. Results-based approaches tend to define an objective, and then offer a payment that is related to the degree to which the objective has been attained (see O'Rourke and Finn, 2020). This is in contrast to "action-based approaches" in which the service provider is provided with a standard payment that reflects the transaction costs and income foregone for undertaking an action-importantly, this payment is independent of the outcome that is achieved (Figure 3).

This approach is most likely for a high-quality environmental outcome that is in demand and targeted by policy (e.g., protection of species-rich grasslands). In typical action-based approaches (a), the payment rate (y axis) is standard (represented by the horizontal dashed line in the left panel) despite the large variation in the delivery of the ecosystem service represented by the distribution of points. In an example from results-based approaches (b), the exact same level of performance is supplied from the same farms in the left panel, but the payment rate is related to the level of supply of the ecosystem service: the higher the level of supply, the higher the payment. In this example, there is a threshold level of quality below which a low or no payment is made. In this scenario, some farms do not receive a results-based payment. From a scheme perspective, this may represent a form of targeting; however, these farms may participate in other more relevant schemes, or may receive nonproductive investments that allow them to increase their score over time and then be eligible to receive payments. Looking to the future, such more targeted approaches may better attract dairying systems to participate in approaches that aim to improve specific environmental objectives. A good example of such an environmental objective would be carbon conservation on farmland. This could (1) reward farmers for continuing farming practices that protect existing stocks of carbon on farmland and grassland (e.g., conservation of permanent grassland, continuation of carbon-conserving practices and protection of hedges and woodland) and (2) incentivise practices that increase carbon sequestration where it is considered to be a scientifically valid opportunity (e.g., conversion of tillage to permanent grassland, adoption of carbon-conserving practices to increase $\mathrm{C}$ sequestration on grassland, planting of woody vegetation).

\section{PAYMENT FOR ECOSYSTEM SERVICES: POTENTIAL FOR PUBLIC-PRIVATE PARTNERSHIPS}

The emergence of public-private partnerships for the provision of environmental public goods is one of the innovations that may arise through up-scaling of results-based approaches. To date, the prevailing view about agri-environment schemes has been dominated by the provision of environmental public goods being delivered through public payments from the national (or international) taxpayer. Such efforts were originally required because of market failure to internalize the negative/positive impacts of some types of production systems. The growing market awareness and reliance of food brands on sustainability standards represents an effort to internalize the environmental benefits of farming systems i.e., brands want to be associated with practices that are good for soil, water, climate and biodiversity (among other attributes). However, with this internalization of the reputational benefits of sustainability standards also comes with it the possibility of internalization of the costs of achieving these sustainability standards. Might we see greater interest in public-private partnerships that result in some combination of public and private payments for environmental goods and services? If so, it is difficult to see such an approach that would not involve clear and verifiable delivery of the stated standards. Therefore, results-based approaches (see Figure 3B) have a strong role in the delivery of public-private partnerships for delivery of ecosystem services. There are some examples of
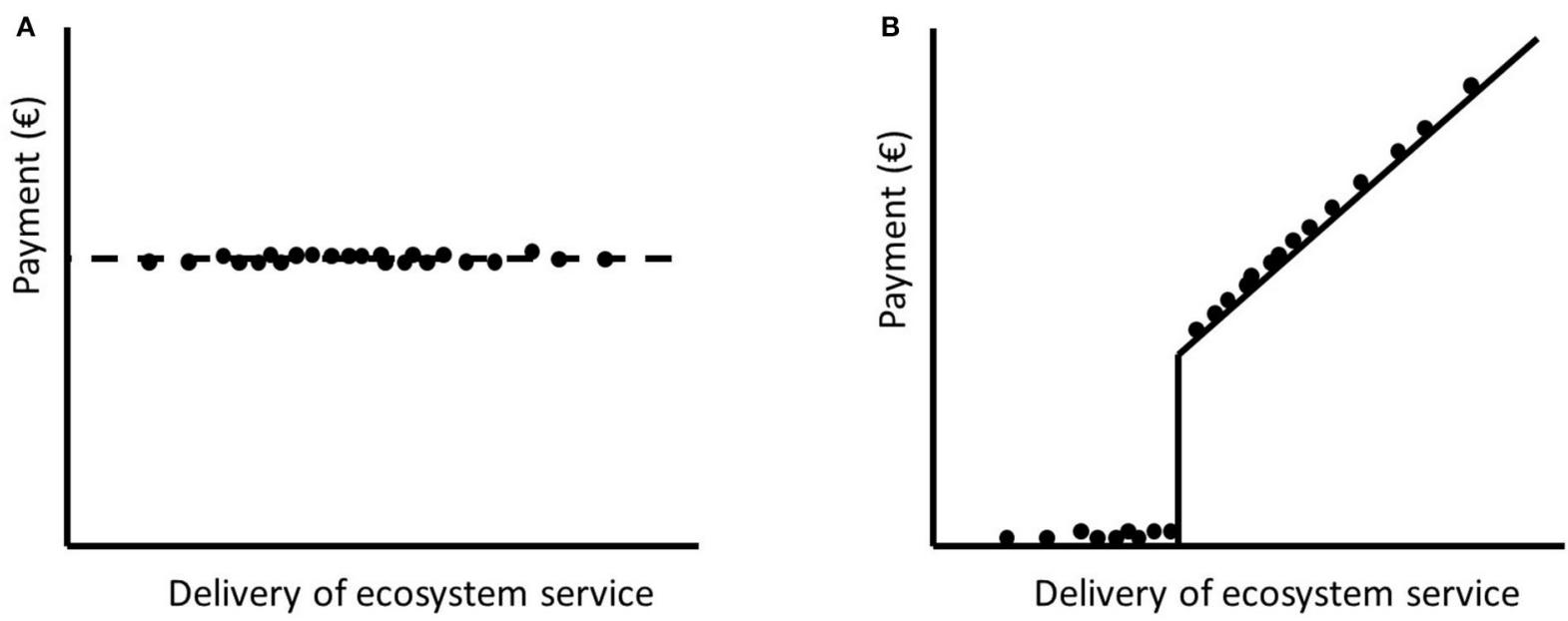

FIGURE 3 | Comparison in the distribution of payments in relation to level of outcome in (A) action-based approaches and (B) results-based approaches (adapted from O'Rourke and Finn, 2020). 
this across Europe e.g., Pro Weideland programme in Germany, and TerraSuisse in Switzerland.

The Pro Weideland programme promotes grazing as nature-oriented husbandry, with its positive influences on environmental protection, animal welfare, and biodiversity. What is especially interesting about the Pro Weideland example is its market-facing approach, and its governance structure. The initiative arose out of a stakeholder-based response to consumer demands for dairy systems that are better for the environment and animal welfare. Farmers receive a premium for their milk that is determined (and paid) by the processor, and varies from one to four cent (€ currency) per liter, depending on the different participating co-operatives. In 2020, about 1,500 farmers participate in the PW programme (and this number is growing). The label is supported by strict standards, a legal entity to manage the programme, and independent monitoring of the procedures and implementation.

The Swiss organization for integrated farming (IP-Suisse) comprises about one quarter of Swiss farmland. In 2009, IPSuisse incorporated a Credit Points System (CPS) in their production guidelines. Based on expert knowledge, the CPS is a predictive tool that includes farmers' efforts for biodiversity on the farm, and allocates points for management practices that increase the wildlife value of farmland. The scores are correlated with biodiversity (Jenny et al., 2013), and producers associated with IP-Suisse have to reach a defined point score. Produce from IP-Suisse farmers are sold by the large Swiss retailer Migros under the "TerraSuisse" label. In addition to the state-funded environmental payments for ECAs, farmers also receive a payment from Migros (Jenny et al., 2013). Importantly, the TerraSuisse approach and related initiatives also enhance the public perception of farming and farmers. This is also a good example of a public-private partnership in which the TerraSuisse approach uses market instruments to add (financial and biodiversity) value to the federal public payments for ecological compensation areas.

\section{CONCLUSION}

Pasture-based systems have many positive aspects in their production of healthy food from livestock fed on grassland forage, which is not directly utilizable as food by humans. This is well-known and recognized by consumers. However, over the last 50 years of intensification, increased stocking rates and associated agrichemical inputs have resulted in multiple environmental impacts. In temperate areas, there is a questionable reliance on systems that are dominated by perennial ryegrass monocultures supported with high levels of inorganic fertilization, the removal of hedges and drainage ditches to facilitate grazing and

\section{REFERENCES}

Alexandratos, N., and Bruinsma, J. (2012). World Agriculture Towards 2030/2050: The 2012 Revision. ESA Working paper $N^{\circ} 12-3$. Rome: FAO.

Arneth, A., Denton, F., Agus, F., Elbehri, A., Erb, K., Osman Elasha, B., et al. (2019). "Framing and context," in Climate Change and Land: An IPCC Special mechanization, and increasing use of concentrates in dairy feeding. As food demand increases, consumers want to know more about the production system both in terms of the environmental impact and the welfare of animals. We highlight an opportunity for pasture-based systems to be more consistent with societal demands, and to transform this demand into success. This challenges animal science to develop a type of cow that is well-adapted, robust, and appropriate for the system. Multispecies pastures are one practical farm-scale response to questions around nutrient use efficiency, feed self-sufficiency and forage quality, biodiversity, and long-term $\mathrm{C}$ sequestration. On the periphery of the grazing platform, the presence and appropriate management of hedgerows can increase the contribution to biodiversity, and promote ecological habitats and niches. These positive practices contribute to a de-intensification of the dairy system, and will partially change the objectives for breeders of both livestock and forage plants. Consequently, this contribution of livestock farming to ecosystem services has to be recognized by consumers and society. Moreover, different forms of payments for ecosystem services need to be developed that target and incentivize positive characteristics. To achieve this successful transition, financial signals from the marketplace can help in addition to agricultural policy supports to encourage the change that is desired by consumers and society, is equitable to farmers and consistent with the goals of sustainable farming.

\section{AUTHOR CONTRIBUTIONS}

This review has been co-written by the 4 co-authors. After a one-day meeting together in Ireland to define the overall plan and divide the sections, each author has made a contribution to the text. $\mathrm{BH}$ : the Introduction. $\mathrm{BH}$ and LD: the chapter The Evolving Role of Lowland Temperate Grassland in Food Systems, Designing Climate-Smart Temperate Grazing Systems, and Matching the Cow to the System. GG: the chapter Multi-Species Mixtures: Benefits of Diversity. JF and GG: the chapter Biodiversity and Ecosystem Service Provision. JF: the chapter Market and Policy Actions to Enhance Biodiversity and Ecosystem Services and Payment for Ecosystems Services: Potential for Public-Private Partnerships. LD: the Conclusion. These different parts have been combined and a 2nd meeting organized to finalize and revise the combined draft. All authors contributed to the article and approved the submitted version.

\section{FUNDING}

GG was supported by the Teagasc Walsh Scholarship Scheme.
Report on Climate Change, Desertification, Land Degradation, Sustainable Land Management, Food Security, and Greenhouse Gas Fluxes in Terrestrial Ecosystems, Chapter 1, eds P. R. Shukla, J. Skea, E. Calvo Buendia, V. Masson-Delmotte, H.-O. Pörtner, D. C. Roberts, P. Zhai, R. Slade, S. Connors, R. van Diemen, M. Ferrat, E. Haughey, S. Luz, S. Neogi, M. Pathak, J. Petzold, J. Portugal Pereira, P. Vyas, E. Huntley, K. Kissick, M. Belkacemi, 
and J. Malley (Geneva: Intergovernmental Panel on Climate Change), $1-98$.

Bargo, F., Muller, L. D., Delahoy, J. E., and Cassidy, T. W. (2002). Performance of high producing dairy cows with three different feeding systems combining pasture and total mixed rations. J. Dairy Sci. 85, 2948-2963. doi: 10.3168/jds.S0022-0302(02) 74381-6

Baumont, R., Lewis, E., Delaby, L., Prache, S., and Horan, B. (2014). "Sustainable intensification of grass based ruminant production," in EGF at 50: The Future of European Grasslands, Grassland Science in Europe, Vol. 19. Proceedings of the 25th General Meeting of the European Grassland Federation (Aberystwyth), 521-534.

Bedere, N., Disenhaus, C., Ducrocq, V., Leurent-Colette, S., and Delaby, L. (2016). Ability of dairy cows to ensure pregnancy according to breed and genetic merit for production traits under contrasted pasture-based systems. J. Dairy Sci. 100, 2812-2827. doi: 10.3168/jds.2016-11588

Bedere, N., Disenhaus, C., Ducrocq, V., Leurent-Colette, S., and Delaby, L. (2017). Ability of dairy cows to be inseminated according to breed and genetic merit for production traits under contrasting pasture-based feeding systems. Animal 11, 826-835. doi: 10.1017/S1751731116002111

Berry, D. P., Buckley, F., and Butler, S. (2019). "Sustainable breeding. What are the options?" in Irish dairying-Growing sustainability, Moorepark'19 (Moorepark: Teagasc, Animal \& Grassland Research and Innovation Centre), 38-45. Available online at: https://www.teagasc.ie/media/website/publications/2019/ Moorepark19-Irish-Dairying-booklet.pdf (accessed December 08, 2020).

Butler, S. T. (2014). Nutritional management to optimize fertility of dairy cows in pasture-based systems. Animal 8(Suppl. 1), 15-26. doi: $10.1017 /$ S1751731114000834

Capper, J. L., and Cady, R. A. (2020). The effects of improved performance in the U.S. dairy cattle industry on environmental impacts between 2007 and 2017. J. Anim. Sci. 98, 1-14. doi: 10.1093/jas/skz291

Ceballos, G., Ehrlich, P. R., and Dirzo, R. (2017). Biological annihilation via the ongoing sixth mass extinction signaled by vertebrate population losses and declines. Proc. Natl. Acad. Sci. U.S.A. 114, 6089-6096. doi: 10.1073/pnas.1704949114

Cong, W., Søegaard, K., and Eriksen, J. (2016). "Diversity promotes production of ryegrass-clover leys through inclusion of competitive forb species," in The multiple roles of grassland in the European bioeconomy, Vol. 21, (Trondheim: Grassland Science in Europe), 557-559.

Cong, W. F., Ruijven, J., Mommer, L., De Deyn, G. B., Berendse, F., and Hoffland, E. (2014). Plant species richness promotes soil carbon and nitrogen stocks in grasslands without legumes. J. Ecol. 102, 1163-1170. doi: $10.1111 / 1365-2745.12280$

Connolly, J., Sebastià, M. T., Kirwan, L., Finn, J. A., Llurba, R., Suter, M., et al. (2018). Weed suppression greatly increased by plant diversity in intensively managed grasslands: a continental-scale experiment. J. Appl. Ecol. 55, 852-862. doi: 10.1111/1365-2664.12991

Cranston, L., Kenyon, P., Morris, S., and Kemp, P. (2015). A review of the use of chicory, plantain, red clover, and white clover in a sward mix for increased sheep and beef production. J. N. Z. Grassl. 77, 89-94. doi: 10.33584/jnzg.2015.77.475

Craven, D., Isbell, F., Manning, P., Connolly, J., Bruelheide, H., Ebeling, A., et al. (2016). Plant diversity effects on grassland productivity are robust to both nutrient enrichment and drought. Philos. Trans. R. Soc. B Biol. Sci. 371:20150277. doi: 10.1098/rstb.2015.0277

Dall-Orsoletta, A. C., Leurent-Colette, S., Launay, F., Ribeiro-Filho, H. M. N., and Delaby, L. (2019). A quantitative description of the effect of breed, first calving age, and feeding strategy on dairy systems enteric methane emission. Livest. Sci. 224, 87-95. doi: 10.1016/j.livsci.2019.04.015

Delaby, K. (2015). Traitement sélectif ciblé des strongyloses gastro-intestinales base sur les variations de gain de poids vif chez les veaux laitiers de $1^{\text {ère }}$ saison de pâturage en Irlande (Thèse de doctorat vétérinaire). Faculté de médecine, Nantes, Oniris, Ecole nationale vétérinaire, agroalimentaire et de l'alimentation, Nantes Atlantique, France, Available online at: http:// kentika.oniris-nantes.fr/GED_BHV/194450291263/na_15_118.pdf (accessed December 08, 2020) (document in english).

Delaby, L., Buckley, F., McHugh, N., and Blanc, F. (2018). "Robust animals for grass based production systems," in Sustainable Meat and Milk Production From
Grasslands, Grassland Science in Europe, Vol. 23. Proceedings of the 27th General Meeting of the European Grassland Federation (Cork), 389-400.

Delaby, L., Faverdin, P., Michel, G., Disenhaus, D., and Peyraud, J. L. (2009). Effect of different feeding strategies on lactation performance of Holstein and Normande dairy cows. Animal 3, 891-905. doi: 10.1017/S17517311090 04212

Delaby, L., and Fiorelli, J. L. (2014). Elevages laitiers à bas intrants: entre traditions et innovations. INRA Prod. Anim. 27, 123-134. doi: 10.20870/productions-animales.2014.27.2.3060

Delaby, L., Hennessy, D., Gallard, Y., and Buckley, F. (2014). "Animal choice for grass-based systems," in EGF at 50; The Future of European Grasslands, Grassland Science in Europe, Vol. 19. Proceedings of the 25th General Meeting of the European Grassland Federation (Aberystwyth), 795-797.

Delaby, L., and Horan, B. (2017). "Improved efficiency in temperate grass based dairy systems," in Anais da 54a. Reunião Anual da Sociedade Brasileira de Zootecnia, 24 a 28 de Juhlo 2017 (Foz do Iguaçu). Available online at: https:// hal.archives-ouvertes.fr/hal-01595681 (accessed December 08, 2020).

Delagarde, R., Roca-Fernández, A., and Peyraud, J. (2014). Prairies multispécifiques avec ou sans chicorée: densité du couvert mesurée à l'herbomètre et composition chimique. Fourrages 218, 177-180.

Delgado, C., Rosegrand, M., Steinfeld, H., Ehui, S., and Courbois, C. (2009). Livestock to 2020: The Next Food Revolution. Food, Agriculture, and the Environment Discussion Paper No. 28. Washington, DC: IFPRI. Available online at: https://cgspace.cgiar.org/bitstream/handle/10568/333/dp28.pdf? sequence $=2$ andisAllowed $=y$ (accessed December 08, 2020).

ECA (2011). Is Agri-environment Support Well Designed and Managed? European Court of Auditors. Special Report $n^{\circ}$ 7. Publications Office of the European Union.

Egan, M., Lynch, M., and Hennessy, D. (2015). "Herbage and milk production from a grass-only sward and grass-white clover swards in an intensive grassbased system," in Grassland and Forages in High Output Dairy Farming Systems, Grassland Science in Europe, Vol. 20. Proceedings of the 18th Symposium of the European Grassland Federation (Wageningen), 93-95.

Erb, K., Lauk, C., Kastner, T., Mayer, A., Theurl, M. C., and Haber, H. (2016). Exploring the biophysical option space for feeding the world without deforestation. Nat. Commun. 7:11382, 1-9. doi: 10.1038/ncomms11382

EU (2009). Scientific report of EFSA prepared by the Animal Health and Animal Welfare Unit on the effects of farming systems on dairy cow welfare and disease. EFSA J. 1143, 1-38. doi: 10.2903/j.efsa.2009.1143

EU (2019). The European Green Deal Brussels, 11.12.2019 COM (2019) 640 final. Available online at: https://ec.europa.eu/info/strategy/priorities-20192024/european-green-deal_en (accessed December 08, 2020).

FAO (2009). How to Feed the World in 2050. Rome: FAO. Available online at: http://www.fao.org/wsfs/forum2050/wsfs-forum/en/ (accessed December 08, 2020).

FAO (2017). The Future of Food and Agriculture-Trends and Challenges. Rome: FAO.

FAO (2020). Biodiversity and the Livestock Sector-Guidelines for Quantitative Assessment-Version 1. Rome: Livestock Environmental Assessment and Performance Partnership (FAO LEAP). https://doi.org/10.4060/ca9295en

Finn, J. A., Kirwan, L., Connolly, J., Sebastià, M. T., Helgadottir, A., Baadshaug, O. H., et al. (2013). Ecosystem function enhanced by combining four functional types of plant species in intensively managed grassland mixtures: a 3-year continental-scale field experiment. J. Appl. Ecol. 50, 365-375. doi: 10.1111/1365-2664. 12041

Finn, J. A., Suter, M., Haughey, E., Hofer, D., and Lüscher, A. (2018). Greater gains in annual yields from increased plant diversity than losses from experimental drought in two temperate grasslands. Agric. Ecosyst. Environ. 258, 149-153. doi: 10.1016/j.agee.2018.02.014

Friggens, N. C., and Newbold, J. R. (2007). Towards a biological basis for predicting nutrient partitioning: the dairy cow as an example. Animal 1, 87-97. doi: $10.1017 /$ S1751731107657772

Fulkerson, W. J., Davison, T. M., Garcia, S. C., Hough, G., Goddard, M. E., Dobos, R., et al. (2008). Holstein-Friesian dairy cows under a predominantly grazing system: interaction between genotype and environment. J. Dairy Sci. 91, 826-839. doi: 10.3168/jds.2007-0147 
Godfray, H. C. J., and Garnett, T. (2014). Food security and sustainable intensification. Philos. Trans. R. Soc. B 369:20120273. doi: $10.1098 /$ rstb.2012.0273

Grace, C., Lynch, M. B., Sheridan, H., Lott, S., Fritch, R., and Boland, T. M. (2019). Grazing multispecies swards improves ewe and lamb performance. Animal 13, 1721-1729. doi: 10.1017/S1751731118003245

Grange, G., Brophy, C., and Finn, J. (2019). "Effects of plant diversity on yield in intensively managed grasslands," in Improving Sown Grasslands Through Breeding and Management, Grassland Science in Europe Vol. 24. Proceedings of the 20th Symposium of the European Grassland Federation (Zurich), 54-56.

Harris, S., Clark, D., Auldist, M., Waugh, C., and Laboyrie, P. (1997). Optimum white clover content for dairy pastures. Proc. N. Z. Grassl. Assoc. 59, 29-34. doi: 10.33584/jnzg.1997.59.2261

Hopkins, A., and Del Prado, A. (2007). Implications of climate change for grassland in Europe: impacts, adaptations, and mitigation options: a review. Grass Forage Sci. 62, 118-126. doi: 10.1111/j.1365-2494.2007. 00575.x

Horan, B., Dillon, P., Faverdin, P., Delaby, L., Buckley, F., and Rath, M. (2005). The interaction of strain of Holstein-Friesian cows and pasture-based feed systems on milk yield, body weight, and body condition score. J. Dairy Sci. 88, 1231-1243. doi: 10.3168/jds.S0022-0302(05)72790-9

Huguenin-Elie, O., Delaby, L., Klumpp, K., Lemauviel-Lavenant, S., Ryschawy, J., and Sabatier, R. (2018). "The role of grasslands in biogeochemical cycles and biodiversity conservation," in Improving Grassland and Pasture Management in Temperate Agriculture, eds A. Marshall and R. Collins (Cambridge: Burleigh Dodds Science Publishing Limited), 3-29. doi: 10.19103/AS.2017.0024.01

IPCC (2019). Climate Change and Land. Summary for Policymakers. Available online at: https://www.ipcc.ch/site/assets/uploads/2019/08/4.-SPM_ Approved_Microsite_FINAL.pdf (accessed December 08, 2020).

Isbell, F., Craven, D., Connolly, J., Loreau, M., Schmid, B., Beierkuhnlein, C., et al. (2015). Biodiversity increases the resistance of ecosystem productivity to climate extremes. Nature 526, 574-577. doi: 10.1038/nature15374

Jenny, M., Zellweger-Fischer, J., Balmer, O., Birrer, S., and Pfiffner, L. (2013). The credit point system: an innovative approach to enhance biodiversity on farmland. Asp. Appl. Biol. 118, 23-30.

Kastner, T., Rivas, M. J. I., Koch, W., and Nonhebel,. S. (2012). Global changes in diets and the consequences for land requirements for food. Proc. Natl. Acad. Sci. U.S.A. 109, 6868-6872. doi: 10.1073/pnas.1117054109

Kleijn, D., Kohler, F., Baldi, A., Batary, P., Concepcion, E. D., Clough, Y., et al. (2009). On the relationship between farmland biodiversity and land-use intensity in Europe. Proc. R. Soc. B 276, 903-909. doi: 10.1098/rspb.2008.1509

Kornhuber, K., Osprey, S., Coumou, D., Petri, S., Petoukhov, V., Rahmstorf, S., et al. (2019). Extreme weather events in early summer 2018 connected by a recurrent hemispheric wave-7 pattern. Environ. Res. Lett. 14:054002. doi: 10.1088/1748-9326/ab13bf

Larkin, J., Sheridan, H., Finn, J. A., and Denniston, H. (2019). Semi-natural habitats and ecological focus areas on cereal, beef, and dairy farms in Ireland. Land Use Policy 88:104096. doi: 10.1016/j.landusepol.2019.104096

Lee, J. M., Clark, A. J., and Roche, J. R. (2013). Climate-change effects and adaptation options pasture-based dairy farming systems: a review. Grass Forage Sci. 68, 485-503. doi: 10.1111/gfs.12039

Mottet, A., de Haan, C., Falcuccia, A., Tempioa, G., Opioa, C., and Gerbera, P. (2017). Livestock: on our plates or eating at our table? A new analysis of the feed/food debate. Glob. Food Sec. 14, 1-8. doi: 10.1016/j.gfs.2017.01.001

Nalon, E., and Stevenson, P. (2019). Protection of dairy cattle in the EU: state of play and directions for policymaking from a legal and animal advocacy perspective. Animals 9:1066. doi: 10.3390/ani9121066

Newbold, T., Hudson, L. N., Hill, S. L. L., Contu, S., Lysenko, I., Senior, R. A., et al. (2015). Global effects of land use on local terrestrial biodiversity. Nature 520, 45-50. doi: 10.1038/nature14324

Nyfeler, D., Huguenin-Elie, O., Suter, M., Frossard, E., Connolly, J., and Lüscher, A. (2009). Strong mixture effects among four species in fertilized agricultural grassland led to persistent and consistent transgressive overyielding. J. Appl. Ecol. 46, 683-691. doi: 10.1111/j.1365-2664.2009.01653.x

O'Mara, F. P. (2012). The role of grasslands in food security and climate change. Ann. Bot. 110, 1263-1270. doi: 10.1093/aob/mcs209

O'Rourke, E., and Finn, J. A. (eds.). (2020). Farming for Nature: The Role of Results-Based Payments. Co. Waterford: Teagasc and National Parks and Wildlife Service. Available online at: www.teagasc.ie/farmingfornature (accessed December 08, 2020).

O'Sullivan, M., Butler, S. T., Pierce, K. M., Crowe, M. A., O'Sullivan, K. O., Fitzgerald, R., et al. (2020). Reproductive efficiency and survival of Holstein-Friesian cows of divergent economic breeding index, evaluated under seasonal calving pasture-based management. J. Dairy Sci. 103, 1685-1700. doi: $10.3168 /$ jds.2019-17374

O’Sullivan, M., Horan, B., Pierce, K. M., McParland, S., O’Sullivan, K. O., and Buckley, F. (2019). Milk production of Holstein-Friesian cows of divergent economic breeding index evaluated under seasonal pasture-based management. J. Dairy Sci. 102, 2560-2577. doi: 10.3168/jds.2018-15559

Peyraud, J. L. (2017). "The role of grassland based production system for sustainable protein production," in Anais da 54a. Reunião Anual da Sociedade Brasileira de Zootecnia, 24a 28 de Juhlo 2017 (Foz do Iguaçu). Available online at: https://hal.archives-ouvertes.fr/hal-01591147 (accessed December 08, 2020).

Plantureux, S., Bernués, A., Huguenin-Elie, O., Hovstad, K., Isselstein, J., McCracken, D., et al. (2016). "Ecosystem services indicators for grassland in relation to ecoclimatic regions and land use systems," in The Multiple Roles of Grassland in the European Bioeconomy, Grassland Science in Europe, Vol. 21. Proceedings of the 26th General Meeting of the European Grassland Federation (Trondheim), 524-898.

Pottier, E., Delaby, L., and Agabriel, J. (2007). Adaptations de la conduite des troupeaux bovins et ovins aux risques de sécheresse. Fourrages 191, 267-284.

Poutaraud, A., Michelot-Antalik, A., and Plantureux, S. (2017). Grasslands: a source of secondary metabolites for livestock health. J. Agric. Food Chem. 65, 6535-6553. doi: 10.1021/acs.jafc.7b00425

Ramsbottom, G., Horan, B., Berry, D. P., and Roche, J. R. (2015). Factors associated with the financial performance of spring-calving, pasture-based dairy farms. $J$. Dairy Sci. 98, 3526-3540. doi: 10.3168/jds.2014-8516

Roca-Fernandez, A., Gonzales-Rodriguez, A., Leurent, S., Gallard, Y., and Delaby, L. (2012). "Milk performance of two cow breeds at two levels of supplementation in long residence time grazing paddocks," in Grassland, A European Resource? Grassland Science in Europe, Vol. 17. Proceedings of the 24th General Meeting of the European Grassland Federation (Lublin), 267-269.

Roca-Fernández, A., Peyraud, J.-L., Delaby, L., and Delagarde, R. (2016). Pasture intake and milk production of dairy cows rotationally grazing on multi-species swards. Animal 10, 1448-1456. doi: 10.1017/S1751731116000331

Rotchés-Ribalta, R., Ruas, S., Ahmed, K. D., Gormally, M., Moran, J., Stout, J., et al. (2020). Assessment of semi-natural habitats and landscape features on Irish farmland: New insights to inform EU Common Agricultural Policy implementation. Ambio doi: 10.1007/s13280-020-01344-6

Ryschawy, J., Martin, G., Moraine, M., Duru, M., et al. (2017). Designing croplivestock integration at different levels: toward new agro-ecological models? Nutr. Cycl. Agroecosys. 108, 5-20. doi: 10.1007/s10705-016-9815-9

Schaub, S., Buchmann, N., Lüscher, A., and Finger, R. (2020). Economic benefits from plant species diversity in intensively managed grasslands. Ecol. Econ. 168:106488. doi: 10.1016/j.ecolecon.2019.106488

Sheridan, H., Keogh, B., Anderson, A., Carnus, T., McMahon, B., Green, S., et al. (2017). Farmland habitat diversity in Ireland. Land Use Policy 63, 206-213. doi: 10.1016/j.landusepol.2017.01.031

Sheridan, H., McMahon, B. J., Carnus, T., Finn, J. A., Anderson, A., Helden, A. J., et al. (2011). Pastoral farmland habitat diversity in south-east Ireland. Agric. Ecosyst. Environ. 144, 130-135. doi: 10.1016/j.agee.2011.07.011

Soussana, J. F., and Lemaire, G. (2014). Coupling carbon and nitrogen cycles for environmentally sustainable intensification of grasslands and crop-livestock systems. Agric. Ecosyst. Environ. 190, 9-17. doi: 10.1016/j.agee.2013.10.012

Sullivan, C. A., Bourke, D., Skeffington, M. S., Finn, J. A., Green, S., Kelly, S., et al. (2011). Modelling semi-natural habitat area on lowland farms in western Ireland. Biol. Conserv. 144, 1089-1099. doi: 10.1016/j.biocon.2010.12.028

Suter, M., Finn, J. A., Connolly, J., Loges, R., and Lüscher, A. (2015). Gain in nitrogen yield from grass-legume mixtures is robust over a wide range of legume proportions and environmental conditions. Procedia Environ. Sci. 29, 187-188. doi: 10.1016/j.proenv.2015.07.253

Teillard, F., Maia de Souza, D., Thoma, G., Gerber, P. J., and Finn, J. A. (2016). What does life-cycle assessment of agricultural products need for more meaningful inclusion of biodiversity? J. Appl. Ecol. 53, 1422-1429. doi: $10.1111 / 1365-2664.12683$ 
Tilman, D., Balzer, C., Hill, J., and Befort, B. L. (2011). Global food demand and the sustainable intensification of agriculture. Proc. Natl. Acad. Sci. U.S.A. 108, 20260-20264. doi: 10.1073/pnas.1116437108

UN (2015). United Nations. Transforming our world: the 2030 Agenda for Sustainable Development A/RES/70/1 United Nations Resolution Adopted by the General Assembly on 25 September 2015. Available online at: https://sustainabledevelopment.un.org/content/documents/21252030 \%20Agenda\%20for\%20Sustainable\%20Development\%20web.pdf (accessed April 23, 2016)

van der Werf, H. M. G., Knudsen, M. T., and Cederberg, C. (2020). Towards better representation of organic agriculture in life cycle assessment. Nat. Sustain. 3, 419-425. doi: 10.1038/s41893-0200489-6

Vogel, A., Scherer-Lorenzen, M., and Weigelt, A. (2012). Grassland resistance and resilience after drought depends on management intensity and species richness. PLoS ONE 7:e36992. doi: 10.1371/journal.pone.00 36992

Washburn, S. P., and Mullen, K. A. E. (2014). Invited paper: genetic considerations for various pasture-based dairy systems. J. Dairy. Sci. 97, 5923-5938. doi: 10.3168/jds.2014-7925

Weigelt, A., Weisser, W., Buchmann, N., and Scherer-Lorenzen, M. (2009). Biodiversity for multifunctional grasslands: equal productivity in high-diversity low-input and low-diversity high-input systems. Biogeosciences 6, 1695-1706 doi: 10.5194/bg-6-1695-2009

White, R., Murray, S., and Rohweder, M. (2000). Pilot analysis of global systems: Grassland Ecosystems. Washington, DC: World Resources Institute. Available online at: https://wriorg.s3.amazonaws.com/s3fs-public/pdf/page_grasslands. pdf

Zijdeman, R., and Ribeira da Silva, F. (2014). Life Expectancy at Birth (Total)ClioInfra Dataverse. Amsterdam: IISH Dataverse. Available online at: https:// clioinfra.eu/Indicators/LifeExpectancyatBirthTotal.html (accessed December 08, 2020).

Conflict of Interest: The authors declare that the research was conducted in the absence of any commercial or financial relationships that could be construed as a potential conflict of interest.

Copyright (c) 2020 Delaby, Finn, Grange and Horan. This is an open-access article distributed under the terms of the Creative Commons Attribution License (CC BY). The use, distribution or reproduction in other forums is permitted, provided the original author(s) and the copyright owner(s) are credited and that the original publication in this journal is cited, in accordance with accepted academic practice. No use, distribution or reproduction is permitted which does not comply with these terms. 